\title{
The Effects of International Financial Reporting Standards on Reporting Quality of Financial Institutions in Ghana
}

\author{
Edmond Amissah (Corresponding author) \\ Lecturer, Department of Entrepreneurship and Business Sciences \\ University of Energy and Natural Resources, Ghana \\ E-mail: edmond.amissah@uenr.edu.gh
}

Paul Hammond

Lecturer, Department of Entrepreneurship and Business Sciences

University of Energy and Natural Resources, Ghana

Reginald Djimatey

Lecturer, Department of Entrepreneurship and Business Sciences

University of Energy and Natural Resources, Ghana

Received: April 15, 2020

Accepted: May 28, 2020

Published: June 30, 2020

doi:10.5296/ijafr.v10i2.16851

URL: https://doi.org/10.5296/ijafr.v10i2.16851

\begin{abstract}
This study sought to examine the reporting quality of financial institutions in Ghana after adopting International Financial Reporting Standard (IFRS) as its official national reporting standard. Using a fixed effect logistic regression, the study compares the earnings management of banks and insurance firms before and after IFRS adoption on reporting quality. The data used was drawn from 51 financial institutions made up of 23 universal banks and 28 insurance companies observed over the period 2003 to 2014. The empirical results indicate that financial institutions exhibit more earnings management during the post-adoption era which is interpreted as a decline in the quality of financial reporting among
\end{abstract}




\section{Mll Macrothink}

International Journal of Accounting and Financial Reporting

ISSN 2162-3082

2020, Vol. 10, No. 2

financial institutions in Ghana. The results documented in this study add to the dearth of literature and contributes to the debate on IFRS adoption and its related impact on reporting quality (earnings management) among financial institutions from the perspective of an emerging market. The study is unique in the sense that it includes the insurance industry where the literature is largely silent especially, on the impact of IFRS adoption by countries on the African continent. Furthermore, unlike previous studies, this paper considers both listed and non-listed firms.

Keywords: IFRS adoption, Reporting quality, Earnings management, Financial institutions, Ghana, Insurance industry, Effect

\section{Introduction}

The proliferation of financial scandals over the years (e.g. Enron, 2001; WorldCom, 2002; Parmalat, 2003, etc.) has awakened the concerns of investors and the international community regarding the quality and credibility of information reported by firms (Cheung et al., 2010; Griffin, Lont, \& Sun, 2009; Li, Pincus, \& Rego, 2008; Morais \& Curto, 2008; Penman, 2003). Considerable effort has been made by regulators in the search for a mechanism that will ensure an improvement in the quality of financial reporting as a result of persistent demand (Onumah et al., 2012). Notable among these interventions is the introduction of "high quality" International Financial Reporting Standards (IFRS) by the International Accounting Standard Board (IASB), that is expected to provide the much-desired high-quality information around the world's financial markets. The IFRS has since been adopted voluntarily or mandatorily, partially or wholly, in several other countries following the EU endorsement.

Extant literature offers several pieces of evidence consistent with the claims that IFRS produce highly reliable, transparent and timely financial statement information (Ahmed, Neel \& Wang, 2013; Daske et al., 2008; Ball, 2006), enhances comparability for users of accounting information (Mbawuni, 2018), and ideally enhance capital allocation (Ames, 2013). On the contrary, other researchers report negative impact of IFRS on reporting quality (e.g. Cameran \& Perotti, 2014; Jeanjean \& Stolowy, 2008; Morais \& Curto, 2008; Hung \& Subramanyam, 2007). They attribute the variations in the quality of financial reporting to differences in the level of implementation and other deep-seated political and economic factors that tend to influence reporting quality. According to Van Tendeloo \& Vanstraelen (2005) financial reporting quality is a function of the quality of accounting standards and their implementation. Prior literature widely support the argument that institutions play a very crucial role in shaping financial reporting outcomes (Gebhardt and Novotny-Farkas (2011). Palea (2013) posits that country's legal and political systems as well as financial reporting incentives tend to shape the quality of accounting of that country. Indeed, the application of IAS reflects combined effects of features of the financial reporting system, including standards, their interpretation, enforcement, and litigation (Barth, Landsman, \& Lang, 2008b).

Consequently, some proponents are of the view that the quality of financial reporting among countries will continue to vary regardless of the fact that uniform accounting standards have 
been adopted (Ball 2006). Moreover, the absence of a global regulator to ensure uniform adoption and enforcement reduces the benefits of common accounting standards (Palea, 2013). This implies that the adoption of IFRS will either have positive or negative impact on the reporting quality of a country depending on the differences in the quality between IFRS, the already existing national accounting standards (GAAP), and the effectiveness of enforcement mechanisms (Ahmed, Neel \& Wang, 2013).

Given that the mere adoption of higher-quality accounting standards does not automatically translate into higher-quality financial reporting (Ball, 2006; Jeanjean Stolowy, 2008) implies that the results obtained from these investigations from the advanced countries cannot be generalised as a fair representation of the situation around the globe especially in Africa due to the significant differences in institutional and organizational frameworks that operate under these continents. Besides, it is widely acknowledged that these two classes of continents differ significantly not only in terms of accounting standards used, investor protection laws in place, and the level of enforcement of these laws (Bova \& Pereira, 2012), but also the effectiveness of their capital markets (Gibson, 2003).

It therefore, becomes pretty crucial that more research on the effect of IFRS adoption on the continent of African be undertaken in order to get a better picture of the situation in the region considering the fact that majority of prior studies focused mainly on European and other advanced countries with very few directed at Africa, more especially, the sub-Saharan Africa (Ames, 2013; Samaha \& Khlif, 2016) to better inform strategic policy direction.

A detailed review of the recent empirical research on IFRS and earnings quality among African studies by Ozili, (2016), also confirms the paucity of research in this all-important area. In particular, a careful examination of the existing literature on IFRS in Ghana reveals that majority of the studies focused on the level of compliance and disclosure (e.g. Aboagye-Otchere \& Agbeibor, 2012; Agyei-Mensah, 2013; Appiah-Kubi \& Rjoub, 2017; Ocansey, \& Enahoro, 2014; Opoku et al., 2016), benefits and challenges (Boateng, Arhin \& Arful, 2014; Inusah \& Dwomor, 2017; Mbawuni 2016) but very few on reporting quality. The few studies that were dedicated to IFRS adoption and earnings quality in Ghana focused mainly on the level and quality of disclosures (Abedana, Omane-Antwi, \& Oppong,2016; Agyei-Mensah, 2013) to the apparent neglect of the primary proxies for reporting quality (earnings management, timely-loss recognition and value relevance).

Currently, empirical evidence showing the effectiveness of IFRS in reducing the earnings management practices of financial institutions in Ghana after more than a decade of its implementation is virtually missing from literature. This study therefore, contributes to the literature by providing empirical evidence of the impact of IFRS adoption on earnings management among banks and insurance firms in Ghana.

Secondly, the study adds to the database on IFRS and earnings management by providing direct empirical evidence from an emerging market in the Sub-Saharan African Country, where regulatory environment is perceived to be weak with a lax monitoring and enforcement of IFRS compliance (Assenso-Okofo et al., 2011). 


\section{$\Lambda$ Macrothink}

International Journal of Accounting and Financial Reporting

ISSN 2162-3082

Thirdly, the study contributes to the literature on IFRS adoption by considering both listed and unlisted companies. The study overcomes the self-selection bias by most prior studies which focused mainly on listed firms (e.g. Agyei-Mensah, 2014; Appiah-Kubi \& Rjoub, 2016; Bova \& Pereira, 2012; Elbannan, 2010). Uwuigbe et al., 2016 etc.).

Again, this study contributes to literature by including the insurance companies in its analysis to better understand the impact of IFRS on this neglected sector by researchers. Undoubtedly, current literature on IFRS is largely silent on insurance companies. Even the few studies that considered the financial institutions mainly concentrated on banks (see Gautam, 2011; Günther Gebhardt \& Novotny-farkas, 2010; Manganaris et al., 2015; Shen \& Chih, 2005; Umoren \& Enang, 2015; Uwuigbe et al., 2016). The lack of research focused specifically on the financial sector in developing countries and the findings that reveal the impact of the IFRS adoption on the financial institutions including insurance firms suggest the need for further research to bridge the gap.

Aside the paucity of literature in the financial sector, our selection of the financial institutions was significantly influence by the fact that it is one of the first sectors to fully implement the IFRS effective 2007 after it was officially adopted in 2007. Besides, the financial institutions is the most highly regulated sector in the Ghanaian economy and among the most sophisticated users of financial statements. Moreover, the financial institutions play a pivotal role to the economic development of the Nation, contributing Gh $₫ 11,752$ million to the country's overall GDP in 2018.

The main purpose of this study is to determine the effect of International Financial Reporting Standard (IFRS) on reporting quality in the financial institutions in Ghana. The outcome of this study will provide evidence on the impact of the IFRS adoption on one of the major sectors of the Ghanaian economy and help in evaluating the intended purpose of enhancing reporting quality through global harmonization of accounting standards.

Given that, accounting standard is of higher quality if the standard is capable of either limiting managerial discretion over accounting choices or inherently disallows smoothing or overstatement of earnings (Ahmed et al. (2013), we employ two traditional metrics of earnings management; managing earnings to avoid losses and managing earnings to just meet-or-beat the prior year's earnings and compare the effectiveness of the domestic GAAP with the IFRS in reducing earnings management among selected financial institutions over the study period.

We find evidence of increase earnings management practices (loss avoidance and small positive earnings) under both proxies after IFRS adoption which indicate a decline in reporting quality. The rest of the paper progresses as follows: Section 2 captures the literature review and the hypothesis development. Section 3 describes the sample and the methodology used. Section 4 highlights empirical findings and robustness tests and Section 5 concludes. 


\section{Macrothink Interational Jornal of Acesenting and Finactil Reporting ISSN 2162-3082 2020, Vol. 10, No. 2}

\section{Literature Review and Hypothesis Development}

\subsection{Theory}

The study considers agency theory more attractive and applicable to this study, in that, it considers the shareholders as the principals and directors as agents functioning as a monitor of mechanisms to minimize agency cost. The separation of ownership from control require that corporate control mechanisms are instituted to monitor the activities of the agents in order to guarantee that actions that benefits the agents equally benefit the owners. Corporate control mechanisms are the means by which managers are disciplined to act in the investors' interest" (Bushman \& Smith, 2001). Corporate control mechanisms according to Bushman and Smith (2001) embrace both internal and external mechanisms. They explain that internal mechanisms include; managerial incentive packages, monitoring of directors and the internal labour market while external control mechanisms also involve debt holder monitoring, the market for corporate control, and competition in the product market, the external managerial labour market and securities laws that protect outside investors against expropriation by corporate insiders. From the perspective of agency theory, the adoption of IFRS is considered as an institutional measure that seeks to reduce the opportunistic behaviours of managers (agents) and align the interest of shareholders with that of the managers through transparent reporting as it demands more detailed disclosure information than most previous local GAAP. This study therefore employs agency theory to examine how the adoption of IFRS, which is deemed to bring credibility, accountability and efficiency to financial market around the globe may have contributed to improving or worsening opportunistic actions of agents and the information asymmetric problems associated with agency relationships.

\subsection{Financial Reporting Quality}

The import of financial reporting is to provide faithful and relevant information to all users for informed economic decisions. Therefore, financial reporting is of "high quality" if it meets the needs of the users and assists them to make sound economic decisions. Thus, the relevance of financial statements to shareholders and all other parties contracting with the firm (Ball \& Shivakumar, 2005). Quality was originally thought to mean reliable information that reflects actual transactions about the firm's operations, and is supported by documentation (Cheung et al., 2010). Conceptually, Financial reporting quality is defined as the accuracy with which financial reporting convey information about the firm's operations to users. Management mostly report their performance to shareholders/investors in the form of earnings through the financial statements. In general, accounting earnings is an instrument for evaluating financial reporting (Ball \& Shivakumar, 2005). Therefore, the quality of the financial report would basically be based on the quality of the earnings reported to shareholders and other users. Other studies also view quality earnings in terms of the predictive value of the information provided. Earning quality is therefore measured by how well the current earnings is able to predict into the company's future earnings or the degree to which reported earnings faithfully reflect the economic ramifications of the underlying transactions and events (Cohen, 2003; Yee, 2006).

Although, instruments for measuring varies, researchers have measured quality along the 
lines of primary qualitative characteristics (relevance and faithful representation) as well as the secondary characteristics (understandability, comparability, verifiability and timeliness) of accounting information. Proxies commonly used by researchers include persistence, accruals, smoothness, timeliness, loss avoidance, investor responsiveness, and other external indicators of quality for measuring "earnings quality" (Dechow et al., 2010). Extant literature reveals earnings management, timely loss recognition, and value relevance as the three primary dimensions under which earnings quality has been measured. One of the methods of determining the quality of reported earnings is to determine the degree to which earnings are managed, with the motive of either misleading some stakeholders regarding the fundamental performance of the firm or to influence contractual outcomes which is contingent on the current earnings (Healy \& Wahlen, 1999). Financial reporting quality shall be measured by the level of earnings management in the context of this study sharing in the view of Barth et al. (2008b), that the level of accounting quality can be influenced by managers' opportunistic decisions and actual mistakes in determining accruals.

\subsection{IFRS and Reporting Quality}

Several studies have been conducted to compare various national accounting standards (GAAP) to the much-acclaimed transparent reporting standards (IFRS) using various proxies. For instance, studies which compared the US rules-based GAAP with the more principles-based (IAS/IFRS) on the basis of their ability to reduce earnings management found no significant difference in earnings management through accruals except that earnings management is significantly higher under research and development investment for firms reporting under IAS/IFRS (Liu et al., 2014). The superiority of US GAAP relative to IFRS is also evident in terms of its future cash flow predictability (Atwood et al., 2011). The results of studies that compared the German GAAP with the IAS were mixed. While a study by Bartov, (2002) found both US. GAAP- and IAS to be superior in terms of reporting quality (value relevance), other similar studies found no convincing proof indicating that IAS enhances the reporting quality (Van Tendeloo \& Vanstraelen, 2005; Hung and Subramanyam, 2007).

The situation in Italy is not different from that of Germany as findings were inconclusive. While some researchers report absolute improvement in the value relevance under IFRS (e.g. Paglietti, 2009), other researchers demonstrate that the switch from the Italian GAAP to the IFRS did not enhance the quality of financial reporting but rather reduced it (e.g. Cameran, Campa and Pettinicchio, 2014). Paglieitti, (2009) attributes findings to variation in Italy's country-specific_factors during the IFRS adoption era which is expected to enhance the quality of financial reporting. Cameran et al. (2014), on the other hand attribute the reduction in reporting quality to preparers exploiting the level of flexibility embedded in IFRS to their own reporting advantage. Contrary to the opposing results recorded in Germany and Italy, results from Australia unanimously adjudged the Australia GAAP to be superior relative to the IFRS. Major studies that compared the reporting quality of the two standards measured through accrual reliability ( see Lai and Taylor (2013) and value relevance (see Goodwin, Ahmed and Heaney, 2008) found the Australian GAAP as a better option in reducing earnings management practices. 


\section{Mll Macrothink}

International Journal of Accounting and Financial Reporting

ISSN 2162-3082

2020, Vol. 10, No. 2

George (2008) considered the impact of the IFRS adoption in United Kingdom. The result of the study suggests that IFRS adoption leads to decline in earnings management and enhances the value relevance of accounting information which is interpreted as an indication of higher reporting quality. The effects of the transition from Greek GAAP to IFRS on the financial results of Greek listed firms have been tested by Iatridis and Rouvolis (2010). The study document that the implementation of IFRS result in more value relevant accounting measures indicating a higher quality reporting.

It is evident from the foregoing analysis that studies that compared home country accounting standards with IAS/IFRS among the EU and US GAAP provides mixed results. Aside sample selection biases, methodological issues could as well account for the differences in the results, in that these factors are capable of reducing the test power in these types of studies.

The adoption of the IFRS among developing countries where law enforcement is said to be weak have equally sparked conflicting viewpoints (Ozilis, 2016) . Prather-kinsey (2006) claims that developing-country GAAP converging with IAS/IFRS can result in relevant and reliable information in developing countries. These claims were validated through studies from two emerging markets: South Africa and Mexico measured through value relevance and timeliness of loss recognition. The findings however established that the application of IFRS enhances the quality (value relevance) of some aspect, but not the entire financial reporting components (Ames, 2013). Prior studies from emerging markets supports the notion that the adoption of IFRS result in an improvement in the reporting quality in an environment where law enforcement is putatively high. For example studies conducted in Malaysia highlight that earnings reported under the IFRS regime exhibit less earnings management and more value relevant (Alali \& Foote, 2012; Adibah Wan Ismail et al., 2013). Results from South Africa however show a conflicting result. Yeboah and Yeboah (2015), use 181 firms to test the effectiveness of IFRS in reducing earnings smoothing and discretionary accruals in South Africa. Their findings indicate that earnings quality improved during post-IFRS adoption period, which is contrary to the outcome of prior study by Ames (2013). Although their methodologies were similar, Ames (2013) limited his studies to the listed firms in South Africa. In other emerging markets with limited enforcement resources, like Kenya similitude to other African countries, Bova and Pereira (2012) agrees with the findings from prior studies by Outa (2011) and Elbannan (2010) that earnings management does not decrease during post- adoption era under companies adopting IFRS. They argue that the lack of improvement in reporting quality is largely due to the weak enforcement of these standards by regulators and inadequate training of practitioners. Empirical evidence from Nigeria remain inconclusive. While some studies report an improvement in reporting quality (Onalo et al., 2014; Tanko, 2012), other results show a significant decline in reporting quality after convergence (see, Ozili, 2015).

Generalisation of the findings from the above studies using a sample of single country with one set of regulation becomes pretty difficult due to differences across empirical specifications, and small sample size. Callao and Jarne (2010) opine that local comparability is negatively affected if both IFRS and domestic accounting standards are applied in the same country at the same time. Interestingly, several other researchers have made cross-country 


\section{Ml Macrothink}

International Journal of Accounting and Financial Reporting

ISSN 2162-3082

2020, Vol. 10, No. 2

comparisons involving as many, as 46 countries (Houqe et al., 2012), 33 countries (Atwood et al., 2011) and 31 countries (Leuz, Nanda, and Wysocki, 2003). Other similar studies compared firms from 21 countries (Barth et al., 2008b), 20 countries (Ahmed et al., 2013) whiles some focused specifically on the 15 member states of the European Union (Chen, Tang, Jiang, and Lin, 2010). The studies employ several reporting quality barometers such as earnings management, timely loss recognition, value relevance and reporting aggressiveness to determine the reporting quality of firms under study.

What became evident from these cross-country studies is that, harmonization of national accounting standards alone is not enough to deal with management incentives and institutional factors which equally affect reporting quality (Jeanjean \& Stolowy, 2008). Majority of these researchers share the view that the efficacy of protecting investors at the country level explain variations in reporting quality across countries. Thus, countries with strong investor protection have higher chances of reducing earnings management activities of managers' leading to higher quality of reporting (Leuz, Nanda, and Wysocki (2003). They recommended that proponents and regulators such as IASB, SEC, and European Commission shift their attention towards creating common goals rather than developing a universal accounting language (Jeanjean \& Stolowy, 2008). The results also point to the fact that there is better compliance with OECD Corporate Governance Principles of high quality disclosure and transparency as a result of IFRS adoption (Agyei-Mensah, 2013; Müller, 2014).

\subsection{IFRS and Reporting Quality in Banks}

Empirical evidence suggest that earnings management in banks is not uncommon and the practice actually exist in almost all sample countries including U. S. irrespective of the measures (Shen and Chih (2005). The practice is mostly executed through the recognition and measurement of loan loss provision and other income smoothing practices. They explained that the separation of ownership from control actually account for the opportunistic actions of bank managers in making provision for huge losses due to higher demand for conservatism. The application of the new provision also led to the delay in the recognition of loan loss which is as an indication of decline in the quality of reporting(Gautam, 2011). Consistent with the findings by Jeanjean \& Stolowy, (2008) the research highlights the pivotal role of institutional settings in ensuring reporting quality of banks especially in post IFRS period. Based on their findings they suggest that banks need be motivated to assimilate conservative practices in order to enhance value relevance so as to improve accounting quality.

Uwuigbe et al. (2016) examine the extent to which banks listed on Nigerian Stock Exchange engage in income smoothing after IFRS adoption. The authors provide empirical evidence showing that listed Banks rather engage more in incoming smoothing activities after IFRS adoption. Although earnings management towards small positive earnings however reduced over the 4-year period, on the whole, the quality of accounting among listed banks declined after switching from the local GAAP to IFRS. Dwelling on the same Nigeria banking sector, Ozili \& Outa (2019) assess the effectiveness of IFRS in reducing the earnings smoothing activities of 23 Nigerian banks through loan loss provisions practices. Contrary to the findings by Uwuigbe (2016), the findings reveal that IFRS is associated with lower earnings 
smoothing due to the improved disclosures associated with the new standard (IFRS) which suggests an improvement in reporting quality during the post adoption era. They recommend regulatory bodies streamlining activities to limit the level of discretions available to preparers which encourages earnings management among banks.). Based on the above arguments, and the claim that IFRS is a superior standard we formalate the follwing hypothesis:

H1 "the implementation of IFRS will reduce the earning management practices among Banks and Insurance firms in Ghana"

\section{Research Methodology}

\subsection{Sample Selection}

The target population of this study was captured from a total of 267 firms from the financial institutions in Ghana which comprises all banks and insurance companies. The banking industry is made up of 27 universal banks, 137 rural and community banks, and 58 non-banking financial institutions including finance houses, savings and loans, leasing and mortgage firms (Pwc, 2014). The insurance industry consists of 19 life insurance firms and 26 non-life insurance companies (National Insurance Commission, 2014).

In order to conduct a pre- and post-IFRS adoption effect analysis, the study employs stratified probability sampling technique in the selection of firms for the study.The sample selection covers firms within the target group with at least two years application of the local standard: Ghana National Accounting Standard (GNAS) in Ghana and subsequent post- application of the new standard (IFRS) for at least two years. By this criterion, a total of 216 firms have been removed from the sample due to unavailable or incomplete set of data leaving a final sample size of 51 firms, made up of 23 universal banks and 28 insurance companies, including both listed and non-listed firms. Altogether, the sample consists of 530 firm-year observations covering a period of 12 years from 2003 to 2014. This study depended solely on secondary data; the audited annual financial statements of banks and insurance companies selected for the study over the study period. Both soft and hard-copies of audited annual reports were obtained directly from the headquarters of specific banks, Bank of Ghana and National Insurance Commission (NIC) libraries. Data were anlyzed using SmallStata Version 13.

\subsection{Metrics for Reporting Quality}

Given that our data comprises both listed and non-listed firms, we are unable to determine the value relevance of the firms as a metric of earnings quality. As a result, the study focusses on earnings management as the main barometer of reporting quality.

\subsubsection{Earnings Management}

Earnings management is the intentional, deliberate, misstatement or omission of material facts or accounting data, which is misleading and when considered with all the information made available would cause the reader to change or alter his/her judgement or decision" (National Association of Certified Fraud Examiners, 1993, p.12) (quoted in Dechow \& Skinner, 2000). The presence of earnings management is assumed to deplete the quality of the 
earnings (Dechow et al., 2010). Unmanaged earnings is considered as a proxy for high quality earnings. However, evidence of earnings management is taken as an indication of low earnings quality. For the purpose of this study and to test our predictions, we use two metrics of earnings management: managing earnings to avoid losses (Loss Avoidance) and managing earnings towards a small positive net income (SPOS) for benchmark-beating behaviour.

\subsubsection{Earnings Benchmark}

It is conjectured that the most likely area to find earnings management is in the area of loss-avoidance or just meeting or beating prior year's results (Kanagaretnam et al., 2010). Burgstahler and Dichev (1997) therefore suggest the examination of the frequency of small positive earnings as an alternative to examining the extent of earnings management. Prior studies provide sufficient evidence to suggest that managers have a strong incentive to maintain a consistent pattern of earnings increases over a period. Existing literature documents that the motivation for managers to consistently report increases in earnings stem from the fact that, firms that maintain a consistent and established pattern of earnings growth, command a higher price-to-earnings increases multiples with even a higher premium when the pattern is sustained for a longer period (Barth et al., 1995) (cited in Burgstahler \& Dichev, 1997). This premium is completely lost or dramatically reduced when the established pattern is interrupted. DeAngelo et al. (1996) in support of this argument postulate that firms that experience an interrupted pattern of earnings increases all things being equal, will experience an average of $14 \%$ decline in stock return in the year the pattern is broken. These and other factors serve as a strong incentive for managers to manage earnings to avoid the reporting of losses or earnings decreases.

In line with (Barth, Landsman, \& Lang, 2008; Kanagaretnam et al., 2010; Leuz, Nanda, \& Wysocki, 2003) earnings management as a measure of reporting quality is examined using a logit model. This model relates an earnings benchmark indicator (LA, JMBE) to the dummy for IAS/IFRS which is the key experimental variable and to other set of independent variables. Thus, a positive (negative) coefficient of the dummy for IAS/IFRS indicates higher (lower) earnings management with the new standards. The main idea underlying this measure is that management have a strong incentive or prefers to report small positive net income rather than negative net income. The primary evidence of this benchmark beating behaviour according to Burgstahler and Dichev (1997) is mostly reflected in the form of unusually low frequencies of small earnings decreases and abnormal high frequencies of small earnings increases. Thus, we predict that firms will report small positive net income with lower frequency during post adoption period as compared to pre-adoption period.

This model measures the tendency of managers using accounting discretion to avoid losses or to manage earnings towards a small positive net income (SPOS) for benchmark-beating behaviour. A firms-year observation is classified as small profit or small loss if positive (negative) after tax net income falls within the range of 1 percent of lagged total assets (Burgstahler et al., 2006). Following the approach recommended by Degeorge et al (1999) the study ascertained small profit (SPOS) as the bin width of twice interquartile range of the variables (ROA, $\triangle \mathrm{ROA}$ ) multiplied by the negative cube root of the sample size. Based on 


\section{$\Lambda$ Macrothink}

International Journal of Accounting and Financial Reporting

ISSN 2162-3082 2020, Vol. 10, No. 2

this formula, the study applies an interval of 0.002 and 0.0005 as threshold for Loss avoidance (LA) and just meeting or beating prior year's earnings (JMBE) matrix. These thresholds are consistent with prior literature (Kanagaretnam et al., 2010). Earnings Benchmark (EB) is measured by the frequency of loss avoidance (LA) and the frequency of just-meeting-or-beating prior year's earnings (JMBE).

\subsection{Specification of Reporting Quality Variables}

The estimated benchmark model for the overall industry, banks and insurance firms are presented in the model 1, 2 and 3 respectively.

$$
\begin{aligned}
& E B \text { it }=\beta 0+\beta 1 I F R S \text { it }+\beta 2 \text { SIZEit }+\beta 3 \text { GROWTHit }+\beta 4 L E V \text { it }+\beta 5 \text { CHCFOit }+\beta 6 A L L O W \text { it }+ \\
& \beta 7 B I G 4 \text { it }+\beta 8 R E C \text { it }+\beta 9 R E S E R V \text { it }+\beta 10 E F F \text { it }+\varepsilon \text { it } \\
& \text { eqn } 1 \\
& E B \text { it }=\beta 0+\beta 1 I F R \text { it }+\beta 2 \text { SIZEit }+\beta 3 \text { GROWTHit }+\beta 4 \text { GLOANSit }+\beta 5 \text { LEVit }+\beta 6 C H C F O \text { it } \\
& +\beta 7 A L L O W \text { it }+\beta 8 B I G 4 \text { it }+\beta 9 E F F \text { it }+\varepsilon \text { it } \\
& E B \text { it }=\beta 0+\beta 1 I F R S \text { it }+\beta 2 S I Z E \text { it }+\beta 3 \text { GROWTHit }+\beta 4 R E C \text { it }+\beta 5 L E V \text { it }+\beta 6 C H C F O \text { it } \\
& +\beta 7 A L C L A I M S \text { it }+\beta 8 \text { TURNit }+\beta 9 R E S E R V \text { it }+\beta 9 B I G 4 \text { it }+\varepsilon \text { it }
\end{aligned}
$$

\begin{tabular}{|c|c|}
\hline Variable & Definition \\
\hline$E B_{i . t}$ & $\begin{array}{l}\text { Earnings Benchmark represent either LOSS AVOID or JMBE. } \\
\text { LOSS AVOID (LA) is a dummy variable coded as } 1 \text { if the ROA (Profit } \\
\text { before taxes divided by total assets) of the firm is small between the } \\
\text { interval } 0 \text { and } .002 \text { and zero otherwise. } \\
\text { JMBE is a dummy variable, taking the value } 1 \text { if the change in ROA is } \\
\text { within the range of } 0 \text { and } 0.0005 \text {, zero otherwise. }\end{array}$ \\
\hline $\operatorname{IFRS}_{i . t}$ & $\begin{array}{l}\text { Dummy variable, that equals (1) if the institution report under IFRSs, and } \\
\text { zero (0) otherwise. }\end{array}$ \\
\hline$S I Z E_{i, i}$ & Natural logarithm of total assets \\
\hline GROWTH $_{i, t}$ & $\begin{array}{l}\text { Change in total assets from the beginning to the end of the period scaled } \\
\text { by total assets at the beginning of the year. }\end{array}$ \\
\hline$G L O A N S_{i, t}$ & Gross loan balance divided by total assets at the beginning of the period \\
\hline$L E V_{i, t}$ & End of year total liabilities scaled by assets at the end of the period \\
\hline $\mathrm{CHCFO}_{i, t}$ & $\begin{array}{l}\text { Change in cash flows from operations from the beginning to the end of the } \\
\text { period, scaled by total assets at the beginning of the period }\end{array}$ \\
\hline$A L L O W_{i, t}$ & $\begin{array}{l}\text { Loan losses allowance at the end of the period, scaled by last year's total } \\
\text { assets. }\end{array}$ \\
\hline$B I G 4_{i, t}$ & Auditor type which equals1 if the current auditor is a BIG4 or 0 otherwise \\
\hline$E F F_{i, t}$ & $\begin{array}{l}\text { Efficiency measured as ratio of total operating expense scaled by total } \\
\text { revenue. }\end{array}$ \\
\hline$\varepsilon_{i, t}$ & Error term \\
\hline
\end{tabular}

Table 1. Variable definition and measurement 
$\boldsymbol{R E} \boldsymbol{C}_{\boldsymbol{i}, \boldsymbol{t}} \quad$ Gross receivables at the end of the period divided by the total assets at the beginning of the period

$\boldsymbol{A L C L A I M S}_{i, \boldsymbol{t}}$ Measured as allowance for claims at the end of the period, scaled by total assets at the beginning of the period

\begin{tabular}{cl}
\hline $\boldsymbol{T U R \boldsymbol { N }} \boldsymbol{t}_{\text {,1 }}$ & Gross premiums scaled by total assets at the beginning of the period \\
\hline $\boldsymbol{R} \boldsymbol{E S E R V _ { t , \mathbf { 1 } }}$ & $\begin{array}{l}\text { computed as the ratio of the reserve for banking and insurance risks to the } \\
\text { sum of total liabilities and shareholders' equity. }\end{array}$ \\
\hline
\end{tabular}

\subsection{Other Control Variables}

In line with empirical studies ( e. g. Barth et al., 2008; Beathy et al., 2002; Cameran et al., 2014; Kanagaretnam et al., 2008) the study introduced the following independent variables: SIZE GROWTH, CHCFO, LIST ALLOW, LOANS LEV, REC, BIG 4 and TURN to provide incremental explanatory power to the earnings benchmark models. With the exception of Big 4 it is expected that these control variables will have a positive association with both loss avoidance and JMBE models.

\subsection{Resolving Methodological Issues}

In order to be sure of non-existence of multicollinearity among these variables, the variance inflation factor (VIF) was run. The highest correlation occurred between GLOANS and ALLOW at 0.71 . Vieru \& Schadewitz (2010) postulate that VIF score of more than 10 pose serious threat of multicollinearity. The results from the VIF check shows a VIF score of less than 10 for all the independent variables. The highest VIF score was 3.8 which suggest no or insignificant multicollinearity among the dependant variables. In order to reduce the effect of outliers and to ensure a normal distribution of the data set, the original values of most of the variables (e.g. REC, GLOANS, ALLOW) are scaled by total assets at the beginning of the period. Again, natural logarithm function is applied on variables such as size of company (SIZE). Five other variables were measured as categorical variables. The Hausman's specification test is conducted to determine the appropriate regression model, whether random effect or fixed effect models to use and also check for endogeneity of variable i.e. the presence of correlation between the error term and independent variables. The Hauseman specification results shows a very high significant p-value of 0.000 which implies that we reject the null hypothesis and settle on the Fixed-effect as the more suitable model to be used for this objective. To check and correct for problem of autocorrelation and heteroskedasticity which could render the regression results spurious, a robust regression is conducted using the robust regression option in the STATA software.

\section{Results}

\subsection{Descriptive Analysis of Reporting Quality}

Table 3 and 4 below display the correlation results for the entire financial institution for both earnings management proxies. The correlation results show a positive correlation for the main variable of interest (IFRS) with the dependant variable LA but negatively correlated with the JMBE. This seems to suggest that the introduction of IFRS appear to be more effective in 
reducing JMBE practices than in LA practices. The independent variables SIZE, LEV, ALLOW and BIG4 are all negatively correlated with both dependent variables with only REC showing positive correlation with both dependent variables. The regression results below provide more insight on the above subject.

Table 2. Summary statistics - overall industry

\begin{tabular}{lrrrrr}
\hline Variable & \multicolumn{1}{l}{ Obs. } & \multicolumn{1}{l}{ Mean } & Std. Dev. & \multicolumn{1}{l}{ Min } & \multicolumn{1}{l}{ Max } \\
\hline ROA & 530 & 0.0385 & 0.1485 & -2.20339 & 1.202 \\
CHROA & 530 & 0.0002 & 0.165 & -2.033 & 1.0634 \\
SIZE & 530 & 7.8665 & 0.9086 & 5.334096 & 9.7536 \\
GROWTH & 530 & 0.5136 & 1.5355 & -0.99068 & 18.556 \\
GLOANS & 250 & 0.7372 & 0.5515 & 0.031553 & 7.7286 \\
LEV & 529 & 0.7617 & 0.5352 & 0.001792 & 9.9346 \\
CHCFO & 528 & 0.0381 & 0.4662 & -3.48448 & 5.7561 \\
ALLOW & 308 & 0.0779 & 0.1181 & 0.00051 & 1.0757 \\
RESERV & 530 & 0.0496 & 0.0948 & -0.09709 & 1.0842 \\
EFF & 521 & 0.4589 & 0.4428 & 0.000169 & 7.7904 \\
REC & 493 & 0.1605 & 0.4472 & 0.00016 & 8.0311 \\
IFRS & 530 & 0.4698 & 0.4996 & 0 & 1 \\
BIG4 & 530 & 0.6434 & 0.4794 & 0 & 1 \\
LIST & 530 & 0.2585 & 0.4382 & 0 & 1 \\
LA & 530 & 0.166 & 0.3725 & 0 & 1 \\
JMBE & 530 & 0.2849 & 0.4518 & 0 & 1 \\
\hline
\end{tabular}

Table 3. Pearson Correlation Matrix for reporting quality (LA) - Overall industry

\begin{tabular}{|c|c|c|c|c|c|c|c|c|c|c|c|}
\hline \multicolumn{12}{|c|}{ PEARSON CORRELATION MATRIX FOR REPORTING QUALITY (LA) - OVERALL INSTITUTION } \\
\hline | & LA & IFRS & SIZE & GROWTH & LEV & ALLOW & CHCFO & RESERV & REC & BIG4 & EFF \\
\hline LA & 1 & & & & & & & & & & \\
\hline IFRS & 0.0316 & 1 & & & & & & & & & \\
\hline SIZE & -0.23 & 0.5351 & 1 & & & & & & & & \\
\hline GROWTH & -0.05 & -0.062 & 0.0025 & 1 & & & & & & & \\
\hline LEV & -0.045 & 0.04 & 0.0947 & -0.095 & 1 & & & & & & \\
\hline ALLOW & -0.14 & -0.047 & 0.0208 & 0.1001 & 0.0904 & 1 & & & & & \\
\hline CHCFO & 0.047 & -0.03 & 0.009 & 0.0731 & -0.016 & 0.2426 & 1 & & & & \\
\hline RESERV & -0.052 & -0.137 & -0.255 & -0.019 & 0.4152 & 0.0326 & -0.0396 & 1 & & & \\
\hline REC & 0.0008 & -0.181 & -0.27 & 0.4666 & -0.017 & 0.2964 & -0.0262 & 0.115 & 1 & & \\
\hline BIG4 & -0.017 & 0.2219 & 0.3477 & -0.023 & 0.0911 & -0.031 & 0.0332 & -0.116 & -0.177 & 1 & \\
\hline$\overline{\text { EFF }}$ & 0.1479 & 0.164 & 0.2935 & -0.011 & 0.1165 & 0.0305 & -0.0166 & -0.125 & -0.139 & 0.02 & 1 \\
\hline
\end{tabular}




\section{Macrothink \\ International Journal of Accounting and Financial Reporting ISSN 2162-3082 2020, Vol. 10, No. 2}

Table 4. Correlation Matrix for reporting quality (JMBE) - Overall industry

\begin{tabular}{|c|c|c|c|c|c|c|c|c|c|c|c|}
\hline | & JMBE & IFRS & SIZE & GROWTH & LEV & ALLOW & CHCFO & RESERV & REC & BIG4 & EFF \\
\hline JMBE & 1 & & & & & & & & & & \\
\hline IFRS & -0.0636 & 1 & & & & & & & & & \\
\hline SIZE & -0.3468 & 0.5351 & 1 & & & & & & & & \\
\hline GROWTH & 0.0612 & -0.0624 & 0.0025 & 1 & & & & & & & \\
\hline LEV & -0.1566 & 0.04 & 0.0947 & -0.095 & 1 & & & & & & \\
\hline ALLOW & -0.0787 & -0.0466 & 0.0208 & 0.1001 & 0.0904 & 1 & & & & & \\
\hline CHCFO & -0.0055 & -0.0302 & 0.009 & 0.0731 & -0.016 & 0.2426 & 1 & & & & \\
\hline RESERV & 0.0558 & -0.1369 & -0.2547 & -0.019 & 0.4152 & 0.0326 & -0.04 & 1 & & & \\
\hline REC & 0.1978 & -0.1811 & -0.2695 & 0.4666 & -0.017 & 0.2964 & -0.026 & 0.1148 & 1 & & \\
\hline BIG4 & -0.0959 & 0.2219 & 0.3477 & -0.023 & 0.0911 & -0.031 & 0.0332 & -0.116 & -0.177 & 1 & \\
\hline EFF & -0.0319 & 0.164 & 0.2935 & -0.011 & 0.1165 & 0.0305 & -0.017 & -0.125 & -0.139 & 0.02 & 1 \\
\hline
\end{tabular}

\subsection{Empirical Results for Reporting Quality}

In a normal distribution where earnings are unmanaged, it is expected that the cross-sectional distribution of earnings and earnings changes levels will be relatively smooth (Burgstahler \& Dichev, 1997). Figure 1 and 2 present a histogram of the scaled earnings and earnings change variable with histogram interval widths of 0.002 for the range of -0.15 to +0.15 . The figures show a bell-shaped distribution with an irregularity near zero.

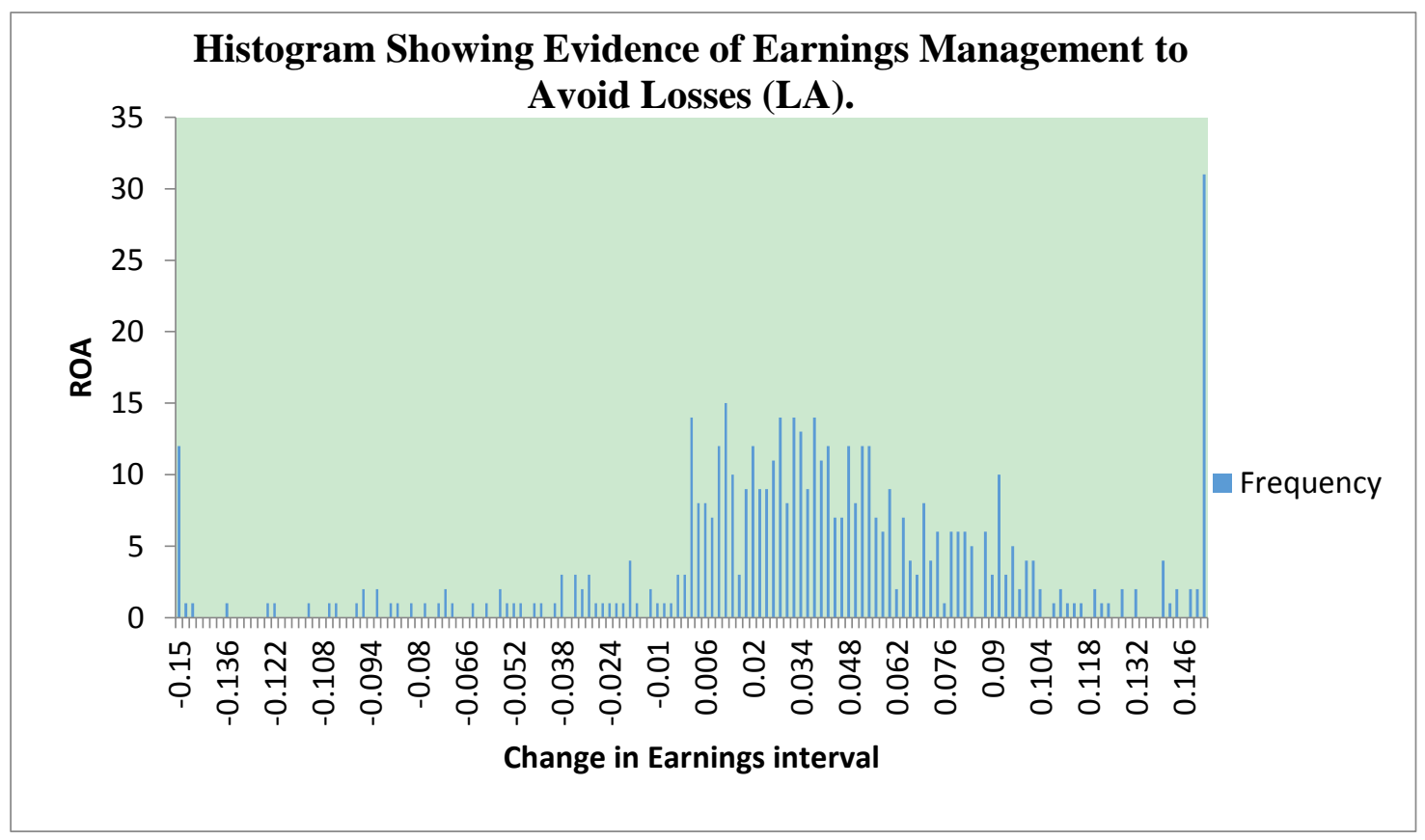

Figure 1. Earnings management to avoid losses 


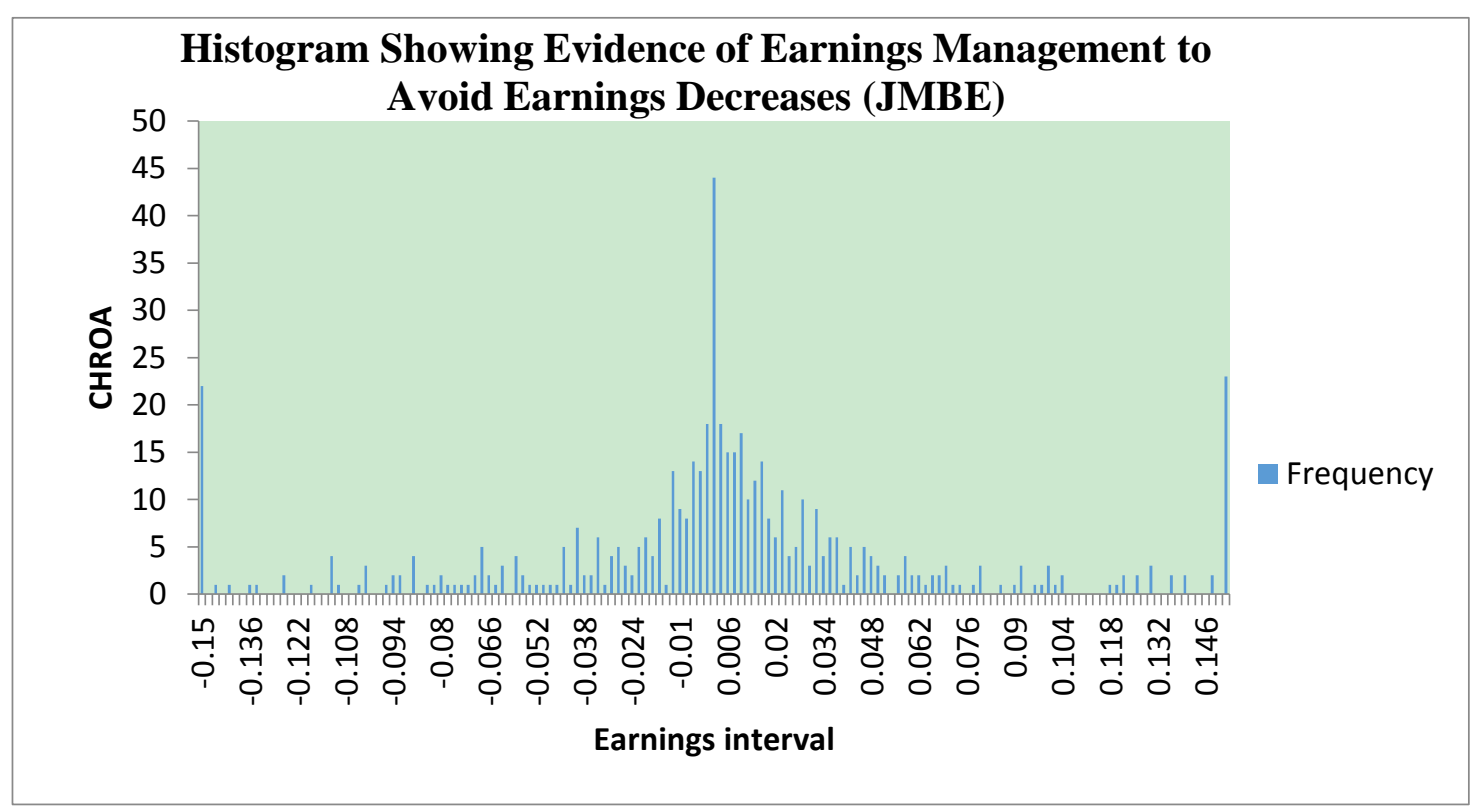

Figure 2. Earnings management to avoid earnings decreases

The study finds that there is more concentration of cases just above zero while there are fewer than expected cases of small losses. In both cases, the frequency of observation above zero is unusually higher relative to the frequencies of losses. These results suggest that firms whose earnings are expected to fall below the zero earnings point or experience earnings decrease engage in earnings management to help them cross the "red line" for the year. This observation is consistent with earnings management to avoid losses or earnings decreases first discovered by Burgstahler \& Dichev (1997) and other subsequent studies on banks (e.g. Shen and Chih, 2005). The study attributes this benchmark beating behaviour to strong incentive by management to maintain a consistent pattern of earnings increases which tend to command higher stock price premium. This findings support the argument by Beathy et al. (2002) and Burgstahler and Dichev (1997) that management smooth earnings to avoid losses or earning decreases; a situation which could result in significant decline in stock prices.

\subsection{Logit Regression Results for Loss Avoidance and JMBE - Overall Financial Institution}

Table 5. IFRS and reporting quality - Overall institution

\begin{tabular}{llrrr}
\hline $\begin{array}{l}\text { Logit model with fixed effect } \\
\text { Column 1 }\end{array}$ & \multicolumn{3}{c}{ LA } & \multicolumn{2}{c}{ Column 2 - JMBE } \\
\hline Number & of obs. & 307 & & 360 \\
Wald & chi2(10) & 60.59 & & 28.02 \\
chi2 & Prob & 0.000. & & 0.0018 \\
\hline & Coef. & z- Stat & Coef. & z- Stat \\
\hline IFRS & $1.3172^{* *}$ & 2.48 & 0.3604 & 1.01 \\
SIZE & $-1.2807^{* *}$ & -2 & -0.1447 & -0.33 \\
GROWTH & -0.4828 & -1.2 & 0.0256 & 0.24 \\
LEV & -1.0916 & -1.16 & $-0.9151^{*}$ & -1.66
\end{tabular}




$\begin{array}{llrcr}\text { ALLOW } & -21.703^{* * *} & -3.06 & -2.9329 & -1.57 \\ \text { CHCFO } & 2.1215^{* * *} & 3.07 & 0.0795 & 0.27 \\ \text { RESERV } & -3.7069 & -0.72 & -3.3398^{*} & -1.68 \\ \text { REC } & -0.1418 & -1.12 & 0.7365 & 1.48 \\ \text { BIG4 } & 0.9247 & 0.86 & 0.8327 & 1.23 \\ \text { EFF } & 3.0245^{* * *} & 3.81 & 1.1285^{* *} & 2.5\end{array}$

Note: $* * * . * * *$ represent statistical significance at $1 \%, 5 \%$ and $10 \%$ respectively

Table 5 above displays the effect of IFRS adoption on earnings management practices of managers of financial institution in Ghana. The coefficient associated to the variable IFRS for LA is positive and significant at the 5\% level. This suggests that banks and insurance firms exhibit higher levels of earnings management during the post IFRS adoption era. Thus, after the switch from the local GAAP to IFRS, financial institutions engage more in managing earnings with the intention to avoid losses entirely. The coefficient for IFRS for the second proxy (JMBE) is also positive but insignificant which implies that the frequency of earnings smoothing to meet a particular target or beat previous target during the IFRS regime is not markedly different from the pre-adoption era.

The overall positive coefficient of the IFRS indicate an increase in the earnings management practices after switching from the local GAAP; Ghana National Accounting Standard to the new standard (IFRS) which suggest a decline in the quality of reporting among the two industries. This suggests that the benchmark beating behaviour of managers of financial institutions in Ghana rather worsened, during the post adoption period. This findings is inconsistent with the widely acclaimed view that IFRS is associated with superior quality of financial reporting (Gebhardt \& Novotny-farkas, 2010; Manganaris, Spathis, \& Dasilas, 2015).

In line with our prediction, coefficient of SIZE is positively associated with both LA and JMBE. This indicates that the frequency of managing earnings to avoid losses or just to beat target is associated with the size of the institution. This result is consistent with the findings of Kanagaretnam et al., (2010) but contradicts the results of earlier studies (e.g. Beathy et al., 2002).

As predicted, the coefficient for ALLOW is positive for both dependent variables and significant for LA which suggest that allowance for loan losses is positively associated with earnings benchmark practices especially in the banks. This observation reinforces the assertion that recognition and measurement of loan loss provision is a major income smoothing mechanism by the financial institutions (Beathy et al, 2002; G̈unther" Gebhardt and Novotny-Farkas, 2011; Cameran et al., 2014). The new predictor variable "EFF" introduced into the model shows a significant positive association with both models which seems to suggest that the level of efficiency of the banks to some extent account for the frequency of benchmark beating behaviours. The positive coefficient of CHCFO shows evidence, as hypothesized, that the frequency of loss avoidance is associated with the changes 
in the cash flows of that entity. Thus, institutions with increases in cash flows are more likely to indulge in loss avoidance practices or to manipulate results to meet or to beat previous earnings (Burgstahler \& Dichev, 1997; Beathy et al., 2002).

\subsection{Logit Regression Results for Loss Avoidance and JMBE - Insurance}

Table 6. IFRS and reporting quality-Insurance firms

\begin{tabular}{|c|c|c|c|c|}
\hline \multicolumn{4}{|l|}{$\begin{array}{l}\text { Column } \\
\text { Column } 2\end{array}$} & 1 \\
\hline Number of obs & & 261 & & 261 \\
\hline Chi2(10) & & 25.52 & & 10.88 \\
\hline \multirow[t]{3}{*}{ Chi2 prob. } & & 0.004 & & 0.3672 \\
\hline & LA & & JMBE & \\
\hline & Coef. & z-Stat & Coef. & z-Stat \\
\hline IFRS & $1.850583^{* * *}$ & 3.99 & $0.5319016^{*}$ & 1.74 \\
\hline SIZE & $-1.295092 * *$ & -2.92 & 0.0912081 & 0.35 \\
\hline GROWTH & -0.1818799 & -0.52 & -0.0037058 & -0.03 \\
\hline REC & 0.5085887 & 0.56 & 0.803043 & 1.64 \\
\hline LEV & -0.0316052 & -0.05 & -0.4696322 & -1.08 \\
\hline CHCFO & 0.4073869 & 0.9 & -0.2095077 & -0.59 \\
\hline ALCLAIMS & -17.60114 & -2.41 & -1.203515 & -0.84 \\
\hline BIG4 & 0.3995416 & 0.88 & 0.3405333 & 1.31 \\
\hline RESERV & -4.286097 & -1.18 & -2.216894 & -1.39 \\
\hline TURN & $-1.196884 * *$ & -2.06 & 0.0864288 & 0.65 \\
\hline _cons & $8.308161 * *$ & 2.56 & -0.8439511 & -0.43 \\
\hline
\end{tabular}

Note: $* * *, * *, *$ represent statistical significance at the $1 \%, 5 \%$, and $10 \%$ respectively.

Table 6 presents the logit regression result for loss avoidance and JMBE for column one and two respectively for the insurance industry. Again, the coefficient for the key variable, IFRS is positive at a very high statistical significance, $p$-value of 0.000 for LA and at 10 percent for JMBE. The high significant level of the coefficient of IFRS indicates that the level of earnings management through frequency of small positive net income increased significantly after IFRS adoption. This indicates that IFRS adoption did not improve reporting quality among banks but, on the contrary, decreased it, which contradict our earlier prediction that the much-acclaimed superior standard (IFRS) will reduce earnings management practices among financial institutions in Ghana. This could be attributed to the lack of effective monitoring and supervision in the sector.

The coefficient of majority of the predictors for JMBE (SIZE, GROWTH, REC, EFF and BIG4) is positive although insignificant, suggesting that the frequency at which insurance managers smooth earnings through JMBE could partly be explained by the changes in these variables. Generally, the increase in the frequency of earnings management through 
benchmark beating is driven by the adoption of the new standard (IFRS), SIZE and level of gross premium (TURN).

\subsection{Regression Results for Loss Avoidance and JMBE - Banks}

Table 7 below shows the logit regression estimation results for the two models. The reported Wald chi-square values of 50.34 and 43 and their respective p-values of 0.000 for both models signify that the models are fit for the data. Prior studies have reported Wald chi-square values of 14.18 and 67.60 for LA and JMBE respectively (Cameran et al., 2014).

Table 7. IFRS and reporting quality-Banks

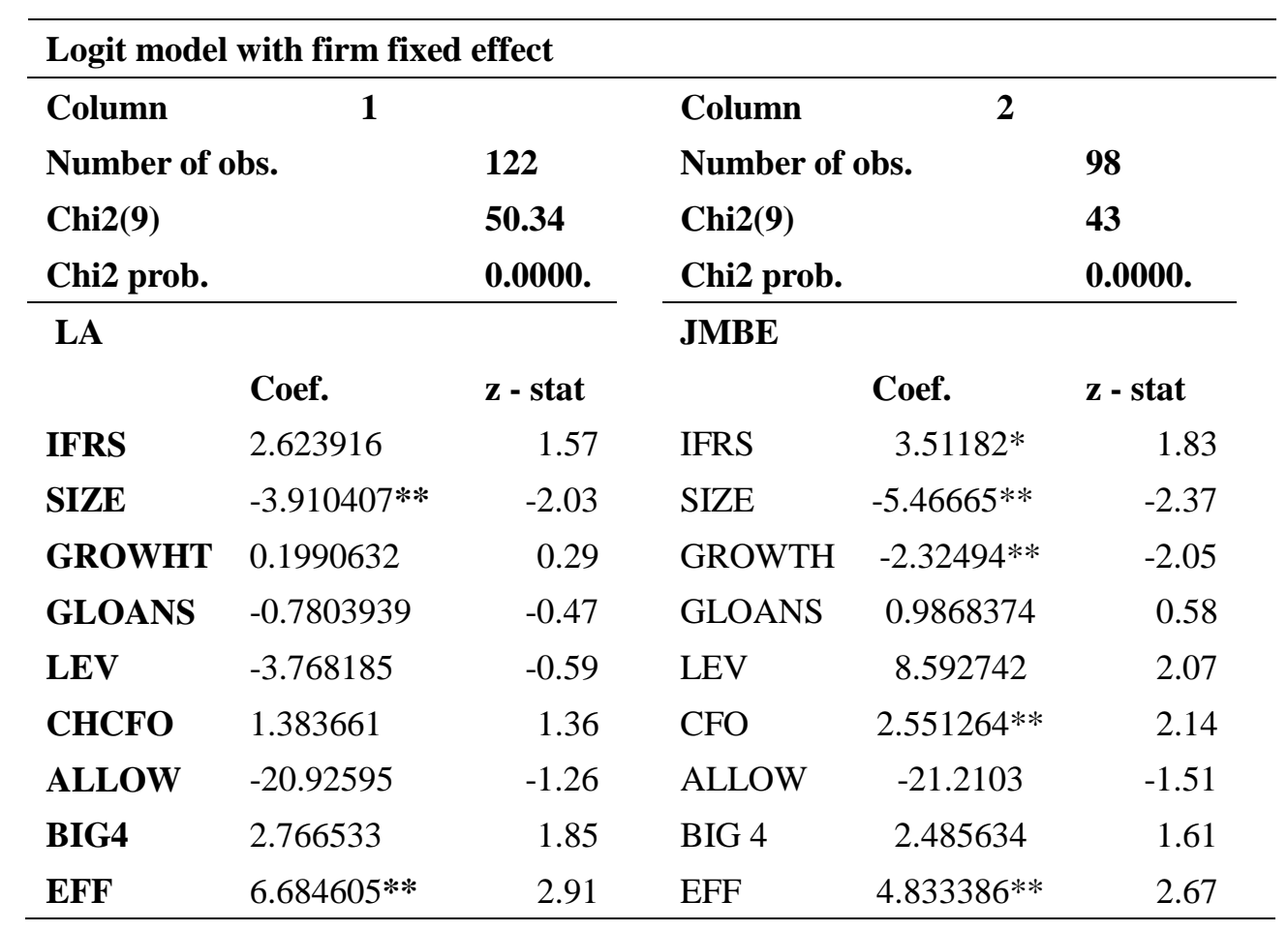

Note: $* * *$ denotes statistical significance at $1 \%$ level

Against our prediction, the coefficients for the primary variable of interest, IFRS for both models are positive although insignificant which suggest a decline in the quality of reporting in the banking sector. This suggests that the benchmark beating behaviour of banks in Ghana rather increased, albeit insignificant during the post adoption period. However, the insignificant coefficient indicates that the decline in reporting quality is not limited to the IFRS adoption but other important factors. Regarding the control variables, with the exception of EFF and SIZE which are significant at 5 percent levels for LA and JMBE, almost all the coefficients of the control variables for LA are insignificant. However, this result is not surprising in the light of prior literature (see Cameran et al., 2014; Kanagaretnam et al, 2010).

With the exception of GROWTH, which is negatively associated with JMBE, CHCFO, BIG4 and EFF are all positively associated with both dependent variables. The negative coefficient of GROWTH for JMBE though unexpected is in line with prior literature (Altamuro \& Beatty, 2010; Hail \& Leuz, 2006). The positive coefficient of the CHCFO suggest that the frequency 
of loss avoidance is associated with the level of cash flows of the banks and consistent with (Burgstahler \& Dichev, 1997; Beathy et al., 2002). Surprisingly, the coefficient of BIG 4 is insignificant but positively associated with the both loss avoidance and JMBE. This suggest that the presence of the international audit firms could not significantly limit the frequency of benchmark beating activities of the banks. This observation is contrary to the findings by (Cameran et al., 2014; Kanagaretnam et al., 2008). GLOANS and LEV are both negatively associated with the frequency of loss avoidance but positively associated with JMBE. This observation is in line with (Cameran et al., 2014; Kanagaretnam et al., 2008) for loss avoidance and (Altamuro \& Beatty, 2010; Hail \& Leuz, 2006) for JMBE. Against prediction, the coefficient for ALLOW is both negative for both dependent variables which suggest that allowance for loan losses cannot be associated with earnings benchmark practices in the banks. This observation is supported by ( Kanagaretnam et al., 2008). The new predictor variable "EFF" introduced into the model shows a significant positive association with both models at 5 percent level which seems to suggest that the level of efficiency of the banks to some extent account for the frequency of benchmark beating behaviours.

\section{Summary of Findings, Conclusion and Recommendations}

Officially, Ghana embraced the new standard (IFRS) in 2007, however, compliance in the form of implementation delayed due to several challenges. The study discovered that majority of the universal banks actually adopted the IFRS in 2008 while most of the insurance companies complied in 2012. The listing status for the selected firms under study were found to be $35 \%$ and $16 \%$ for banks and insurance companies respectively resulting in an average listing status of $26 \%$ for the overall industry. The study finds that the insurance industry experienced much more tremendous growth in assets relative to the banking sector. Nonetheless, the banking industry still remain more profitable than the insurance industry in terms of operating cash flow.

The study finds that the switch from the local GAAP to the new standard (IFRS) did not improve the financial reporting quality among the financial institutions in Ghana. Specifically, the study finds increase in the frequency of earnings management through frequency of small positive net income and loss avoidance among both industries, although insignificant in banks during the post adoption era. We attribute this decline in reporting quality to the lax monitoring and enforcement of compliance.

The results support the widely acclaimed view that the adoption of IFRS in its self does not guarantee higher reporting quality especially in an environment of weak investor protection (Ball 2006; Houqe et al 2012). The empirical evidence validates the results from other countries with perceived weak monitoring and compliance such as Nigeria (e.g. Ozili, 2015), Kenya (e.g. Bova \& Pereira, 2012; Outa, 2011) and South Africa (e.g. Ames, 2015)

This implies that other important country level measures of investor protection such as protection of minority shareholder rights, board independence, enforcement of accounting and auditing standards, and others must be taken seriously. Interestingly, we discovered that the level of earnings management is not necessarily measured by the size of the firm. It also came to light that the presence of the Big 4 could not constrain the level of earnings 
management practices among the financial institutions in Ghana.

From the perspective of agency theory, the adoption of IFRS as a corporate control mechanism intended to restrain the opportunistic behaviour of managers and to reduce the problem of information asymmetry through quality reporting has not been yielded much results.

It is therefore recommended that serious attention be given to other important determinants of reporting quality such as country level investor protection to ensure the full realisation of the benefits inherent in the new standards. It is again recommended that companies, both banks and insurance companies endeavour to fully comply with the new standards to ensure the full realisation of reporting quality that accrue from the adoption of IFRS.

Besides, regulatory and oversight bodies such as the BoG, NIC, SEC, ICAG step up their regulatory and monitoring mechanisms to ensure strong investor protection, enforcement of securities laws, board and judicial independence, freedom of the press, and the protection of minority shareholder rights. Given that managers have the strong incentive to smooth earnings to meet certain target or to avoid losses altogether, auditors should be encouraged to act professionally by improving their professional scepticism to drastically reduce or eliminate any trace of benchmark beating behaviour. This is to ensure highest level of financial reporting quality among the financial institutions.

We recommend that future research to focus on other metrics of accounting quality such as value relevance and timely loss recognition to confirm the findings from this research.

\section{References}

Abedana, V., Omane-Antwi, K., \& Oppong, M. (2016). Adoption of IFRS/IAS in Ghana: Impact on the Quality of Corporate Financial Reporting and Related Corporate Tax Burden. Research Journal of Finance and Accounting, 7(8), 10-25.

Aboagye-Otchere, F., \& Agbeibor, J. (2012). The International Financial Reporting Standard for Small and Medium-sized Entities (IFRS for SMES). Journal of Financial Reporting and Accounting.

Adibah Wan Ismail, W., Anuar Kamarudin, K., van Zijl, T., \& Dunstan, K. (2013). Earnings quality and the adoption of IFRS-based accounting standards. Asian Review of Accounting, 21(1), 53-73.

Agyei-Mensah, B. K. (2013). Adoption of international financial reporting standards (IFRS) in Ghana and the quality of financial statement disclosures. International Journal of Accounting and Financial Reporting.

Ahmed, A. S., Neel, M., \& Wang, D. (2013). Does mandatory adoption of IFRS improve accounting quality? Preliminary evidence. Contemporary Accounting Research, 30(4), 1344-1372.

Alali, F. A., \& Foote, P. S. (2012). The Value Relevance of International Financial Reporting Standards: Empirical Evidence in an Emerging Market. The International Journal of Accounting, 47(1), 85-108. 


\section{$\triangle$ Macrothink}

International Journal of Accounting and Financial Reporting

ISSN 2162-3082

Ames, D. (2013). IFRS adoption and accounting quality: The case of South Africa. Journal of Applied Economics and Business Research, 3(3), 154-165.

Appiah-Kubi, S. N. K., \& Rjoub, H. (2017). Adoption and compliance with ifrs by listed firms in ghana and the extent of financial statement disclosures. Computational Methods in Social Sciences, 5(2), 10-25.

Assenso-Okofo, O., Ali, M. J., \& Ahmed, K. (2011). The development of accounting and reporting in Ghana. The International Journal of Accounting, 46(4), 459-480.

Atwood, T. J., Drake, M. S., Myers, J. N., \& Myers, L. A. (2011). Do earnings reported under IFRS tell us more about future earnings and cash flows?. Journal of Accounting and Public Policy, 30(2), 103-121.

Ball, R. (2006). International Financial Reporting Standards (IFRS): Pros and Cons for investors. Accounting and Business Research, 36(sup1), 5-27.

Ball, R., \& Shivakumar, L. (2005). Earnings quality in UK private firms: comparative loss recognition timeliness. Journal of Accounting and Economics, 39(1), 83-128.

Barth, M. E., Landsman, W. R., \& Lang, M. H. (2008a). International accounting standards and accounting quality. Journal of Accounting Research, 46(3), 467-498.

Barth, M. E., Landsman, W. R., \& Lang, M. H. (2008b). International Accounting Standards and Accounting Quality. Journal of Accounting Research, 46(3), 467-498.

Barth, M. E., Landsman, W. R., \& Wahlen, J. M. (1995). Fair value accounting: Effects on banks' earnings volatility, regulatory capital, and value of contractual cash flows. Journal of Banking \& Finance, 19(3-4), 577-605.

Bartov, E., Goldberg, S. R., \& Kim, M. (2005). Comparative value relevance among German, US, and international accounting standards: A German stock market perspective. Journal of Accounting, Auditing \& Finance, 20(2), 95-119.

Beatty, A. L., Ke, B., \& Petroni, K. R. (2002). Earnings management to avoid earnings declines across publicly and privately held banks. The Accounting Review, 77(3), 547-570.

Bedard, J. C., \& Johnstone, K. M. (2004). Corporate Manipulation Auditors' Pricing. The Accounting Review, 79(2), 277-304.

Boateng, A. A., Arhin, A. B., \& Afful, V. (2014). International Financial Reporting Standard's (IFRS) adoption in Ghana: Rationale, benefits and challenges. Journal of Advocacy, Research and Education, 1(1), 26-32.

Bova, F., \& Pereira, R. (2012). The Determinants and Consequences of Heterogeneous IFRS Compliance Levels Following Mandatory IFRS Adoption: Evidence from a Developing Country. Journal of International Accounting Research, 11(1), 83-111.

Burgstahler, D. C., Hail, L., \& Leuz, C. (2006). The importance of reporting incentives: Earnings management in European private and public firms. The Accounting Review, 81(5), 983-1016.

Burgstahler, D. C., Hail, L., \& Leuz, C. (2006). The importance of reporting incentives: Earnings management in European private and public firms. The Accounting Review.

Burgstahler, D., \& Dichev, I. (1997). Earnings management to avoid earnings decreases and losses. Journal of Accounting and Economics, 24(1), 99-126. 


\section{$\Lambda$ Macrothink}

International Journal of Accounting and Financial Reporting

ISSN 2162-3082

2020, Vol. 10, No. 2

Bushman, R. M., \& Smith, A. J. (2001). Financial accounting information and corporate governance. Journal of accounting and Economics, 32(1), 237-333.

Callao, S., \& Jarne, J. I. (2010). Have IFRS Affected Earnings Management in the European Union?. Accounting in Europe, 7(2), 159-189.

Cameran, M., \& Perotti, P. (2014). Audit Fees and IAS/IFRS Adoption: Evidence from the Banking Industry. International Journal of Auditing, 18(2), 155-169.

Cameran, M., Campa, D., \& Pettinicchio, A. (2014). IFRS Adoption Among Private Companies Impact on Earnings Quality. Journal of Accounting, Auditing \& Finance, 29(3), 278-305.

Chen, H., Tang, Q., Jiang, Y., \& Lin, Z. (2010). The Role of International Financial Reporting Standards in Accounting Quality: Evidence from the European Union. Journal of International Financial Management Accounting, 21(3), 220-278.

Chen, L., Ng, J., \& Tsang, A. (2014). The Effect of Mandatory IFRS Adoption on International Cross-Listings. The Accounting Review, 90(4), 1395-1435.

Cheung, E., Evans, E., \& Wright, S. (2010). An historical review of quality in financial reporting in Australia. Pacific Accounting Review, 22(2), 147-169.

Cohen, D. A. (2003). Quality of Financial Reporting Choice: Determinants and Economic Consequences. Working Paper, New York University, 1-56.

Daske, H., Hail, L., Leuz, C., \& Verdi, R. (2008). Mandatory IFRS reporting around the world: Early evidence on the economic consequences. Journal of Accounting Research, 46(5), 1085-1142.

DeAngelo, H., DeAngelo, L., \& Skinner, D. J. (1996). Reversal of fortune dividend signaling and the disappearance of sustained earnings growth. Journal of Financial Economics, 40(3), 341-371.

Dechow, P., Ge, W., \& Schrand, C. (2010). Understanding earnings quality: A review of the proxies, their determinants and their consequences. Journal of Accounting and Economics, 50(2-3), 344-401.

Degeorge, F., Patel, J., \& Zeckhauser, R. (1999). Earnings management to exceed thresholds*. The Journal of Business, 72(1), 1-33.

Eisenhardt, M. (1989). Agency Theory: An Assessment and Review. Academy of Management Review, 14(1), 57-74.

Elbannan, M. A. (2010). Accounting and Stock Market Effects Of International Accounting Standards Adoption In An Emerging Economy. Rev Quantitative Financial Accounting, 36, 207-245.

Fink, G., Haiss, P., \& Vuksic, G. (2006). 11. Importance of financial sectors for growth in accession countries. Financial Development, Integration and Stability: Evidence from Central, Eastern and South-Eastern Europe, 154.

Gautam. (2011). Mandatory Adoption of IFRS: It's Effect on Accounting Quality, Information Environment and Cost of Equity Capital - The Case of Swedish Banks.

Gebhardt, G., \& Novotny-Farkas, Z. (2011, May). Mandatory IFRS Adoption and Accounting Quality of European Banks. Journal of Business Finance and Accounting, 38, 289-333. 


\section{Macrothink}

International Journal of Accounting and Financial Reporting ISSN 2162-3082

Gibson, M. S. (2003). Is Corporate Governance Ineffective in Emerging Markets? Is corporate governance ineffective in emerging markets?. Journal of Financial and Quantitative Analysis, 38(1), 231-250.

Goodwin, J., Ahmed, K., \& Heaney, R. (2008). The effects of International Financial Reporting Standards on the accounts and accounting quality of Australian firms: A retrospective study. Journal of Contemporary Accounting \& Economics, 4(2), 89-119.

Griffin, P. A., Lont, D. H., \& Sun, Y. (2009). Governance regulatory changes, International Financial Reporting Standards adoption, and New Zealand audit and non-audit fees: Empirical evidence. Accounting and Finance, 49(4), 697-724.

Healy, P. M., \& Wahlen, J. M. (1999). A review of the earnings management literature and its implications for standard setting. Accounting Horizons, 13(4), 365-383.

Houqe, M. N., van Zijl, T., Dunstan, K., \& Karim, A. K. M. W. (2012). The Effect of IFRS Adoption and Investor Protection on Earnings Quality Around the World. International Journal of Accounting, 47(3), 333-355.

Hung, M., \& Subramanyam, K. R. (2007). Financial statement effects of adopting international accounting standards: the case of Germany. Review of Accounting Studies, 12(4), 623-657.

Iatridis, G., \& Rouvolis, S. (2010). The post-adoption effects of the implementation of International Financial Reporting Standards in Greece. Journal of International ACCOUNTING, Auditing and Taxation, 19(1), 55-65.

Inusah, N., \& Dwommor, J. Y. (2017). IFRS Adoption in Ghana. The Dimensions of Challenges Firms Encounter. International Journal of Accounting and Financial Reporting.

Jeanjean, T., \& Stolowy, H. (2008). Do accounting standards matter? An exploratory analysis of earnings management before and after IFRS adoption. Journal of Accounting and Public Policy, 27(6), 480-494.

Kanagaretnam, K., Yeow, C., \& Lobo, G. J. (2010). Auditor reputation and earnings management: International evidence from the banking industry. Journal of Banking and Finance, 34(10), 2318-2327.

Lai, C. Y., Li, Y., Shan, Y., \& Taylor, S. (2013). Costs of mandatory international financial reporting standards: Evidence of reduced accrual reliability. Australian Journal of Management, 38(3), 491-521.

Leuz, C., Nanda, D., \& Wysocki, P. D. (2003). Earnings management and investor protection: An international comparison. Journal of Financial Economics, 69(3), 505-527.

Li, H., Pincus, M., \& Rego, S. O. (2008). Market reaction to events surrounding the Sarbanes-Oxley Act of 2002 and earnings management. Journal of Law and Economics, 51(1), 111-134.

Liu, C., Yip Yuen, C., J. Yao, L., \& H. Chan, S. (2014). Differences in earnings management between firms using US GAAP and IAS/IFRS. Review of Accounting and Finance, 13(2), 134-155.

Manganaris, P., Spathis, C., \& Dasilas, A. (2015). The effects of mandatory IFRS adoption and conditional conservatism on European bank values. Journal of International Accounting, 


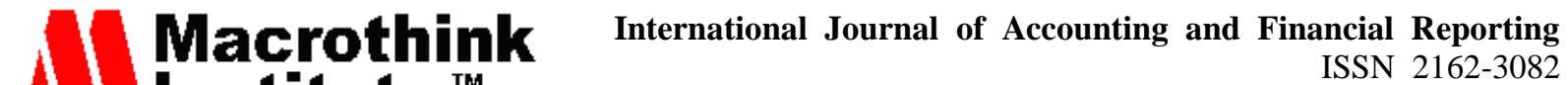 2020, Vol. 10, No. 2}

Auditing and Taxation, 24, 72-81. https://doi.org/10.1016/j.intaccaudtax.2015.02.004

Morais, A. I., \& Curto, J. D. (2008). Accounting quality and the adoption of IASB standards: portuguese evidence. Revista Contabilidade \& Finanças, 19(30), 103-111.

Ocansey, E. O., \& Enahoro, J. A. (2014). Comparative study of the international financial reporting standard implementation in Ghana and Nigeria. European Scientific Journal, $10(13)$.

Onalo, U., Lizam, M., \& Kaseri, A. (2014). The effects of changes in accounting standards on earnings management of Malaysia and Nigeria banks. European Journal of Accounting Auditing and Finance Research, 2(8), 15-42.

Onumah, J. M., Kuipo, R., \& Obeng, V. A. (2012). Effectiveness of internal control systems of listed firms in Ghana. In Accounting in Africa (pp. 31-49). Emerald Group Publishing Limited.

Outa, E. R. (2011). The impact of International Financial Reporting Standards (IFRS) adoption on the accounting quality of listed companies in Kenya. SSRN 1976146.

Ovute, F. E., \& Eyisi, A. S. (2014). Problems and Prospects of Adopting International Financial Reporting Standards in Nigerian Corporate Organization A Study of First Bank of Nigeria PLC. Enugu, 4(6), 1-5.

Ozili, P. K. (2015). Loan loss provisioning, income smoothing, signaling, capital management and procyclicality: does IFRS matter? Empirical evidence from Nigeria. Mediterranean Journal of Social Sciences, 6(2), 224-232.

Ozili, P. K. (2016). Earnings quality and IFRS research in Africa: recent evidence, issues and future direction. Research Journal of Finance and Accounting, 7, 84-94.

Ozili, P. K., \& Outa, E. R. (2019). Bank earnings smoothing during mandatory IFRS adoption in Nigeria. African Journal of Economic and Management Studies.

Paglietti, P. (2009). Investigating the effects of the EU mandatory adoption of IFRS on accounting quality: Evidence from Italy. International Journal of Business and Management, 4(12), 3.

Palea, V. (2013). IAS/IFRS and financial reporting quality: Lessons from the European experience. China Journal of Accounting Research, 6(4), 247.263.

Penman, S. H. (2003). The Quality of Financial Statements: Perspectives from the Recent Stock Market Bubble. Accounting Horizons, 17(s-1), 77.96.

Prather-Kinsey, J. (2006). Developing countries converging with developed-country accounting standards: Evidence from South Africa and Mexico. The International Journal of Accounting, 41(2), 141-162.

Pwc. (2014). Survey The Future of Banking in Ghana ...

Samaha, K., \& Khlif, H. (2016). Adoption of and compliance with IFRS in developing countries: A synthesis of theories and directions for future research. Journal of Accounting in Emerging Economies, 6(1), 33-49.

Shen, C.-H., \& Chih, H.-L. (2005). Investor protection, prospect theory, and earnings management: An international comparison of the banking industry. Journal of Banking \& Finance, 29(10), 2675-2697. 


\section{Macrothink}

International Journal of Accounting and Financial Reporting

ISSN 2162-3082 2020, Vol. 10, No. 2

Subramanyam, M. H. K. R. (2007). Financial Statement Effects of Adopting International Accounting Standards: The Case of Germany. The Accounting Review, 83(2), 447-478.

Van Tendeloo, B., \& Vanstraelen, A. (2005). Earnings management under German GAAP versus IFRS. European Accounting Review, 14(1), 155-180.

Vieru, M., \& Schadewitz, H. (2010). Impact of IFRS transition on audit and non-audit fees: evidence from small and medium-sized listed companies in Finland.

Yaacob, N. M., \& Che-Ahmad, A. (2012). Audit Fees After IFRS Adoption: Evidence from Malaysia. Eurasian Business Review, 2(1), 31-46.

Yee, K. K. (2006). Earnings Quality and the Equity Risk Premium: A Benchmark Model. Contemporary Accounting Research, 23(3), 833-877.

\section{Copyright Disclaimer}

Copyright for this article is retained by the author(s), with first publication rights granted to the journal.

This is an open-access article distributed under the terms and conditions of the Creative Commons Attribution license (http://creativecommons.org/licenses/by/4.0/) 